\title{
Government Subsidies and Firm Technological Innovation Performance: An Empirical Study Based on Panel Data of High-tech Firms
}

\author{
Kun Xie ${ }^{1}$, Zhengluan Zhang ${ }^{2 *}$ \\ ${ }^{1}$ School of Economics and Management, Shanghai Institute of Technology, Shanghai, China \\ ${ }^{2 *}$ School of Economics and Management, Shanghai Institute of Technology, Shanghai, China
}

\begin{abstract}
Can government subsidies improve enterprises' technological innovation performance? Based on the A-share high-tech listed enterprises in Shanghai and Shenzhen Stock Exchange from 2015 to 2019, this paper empirically tests the micro policy effect of government subsidies on innovation performance of enterprises under the background of economic transformation, and the moderating effect of regional corruption, market competition and enterprise ownership concentration on this effect. The results show that the high quality signal transmitted by government subsidies is helpful for innovative enterprises to broaden the source of innovation resources and encourage enterprises to actively carry out innovative activities. Moderate level of regional corruption will promote the government subsidy effect, too high or too low level of corruption is not conducive to enterprise innovation; The higher the degree of market competition, the weaker the promoting effect of government subsidies on enterprise innovation; Corporate ownership concentration has a U-shaped moderating effect on government subsidies and innovation performance. Therefore, to improve the independent innovation ability of enterprises, on the one hand, we should continue to strengthen the government innovation subsidy and improve the subsidy system; on the other hand, we should strictly crackdown on corruption activities and supervise the establishment and improvement of the internal control system of enterprises, so as to give full play to the effect of government subsidies.
\end{abstract}

\section{Introduction}

In recent years, under the background of the new normal, China has formulated a series of policies to support enterprise innovation activities in order to promote the transformation and upgrading of the economic development mode and improve the ability of independent innovation. The 2019 Government Work Report puts forward the task of "insisting on innovation-led development and fostering and strengthening new drivers of growth", which shows that innovation has once again been placed at the level of national strategy and is highly valued by the central government. In 2020, the Fifth Plenary Session of the 19th CPC Central Committee put forward "adhere to the core position of innovation in the overall modernization of China, science and technology self-reliance as a strategic support for national development". In this context, how to improve the independent innovation capability of enterprises and countries has become one of the key topics of academic circles and policy makers.

However, due to the high risk of enterprises' technological innovation activities and the public goods nature of innovation achievements, there may be "market failure" in technological innovation, that is, enterprises' R\&D input may be lower than the social optimal level, which provides theoretical support for the government's innovation subsidies ${ }^{[1]}$.The purpose of government R\&D funding is to drive the scientific and technological innovation of the whole society by promoting the output spillover effect of enterprises' independent R\&D investment ${ }^{[2]}$

However, the academic community has not yet reached a unified view on whether there is a significant relationship between government subsidies and enterprise technological innovation performance and how close this relationship is, but the current mainstream view is that government subsidies can promote enterprise technological innovation performance. Some scholars believe that government subsidies can transmit high-quality signals ${ }^{[3]}$, increase enterprise income ${ }^{[4,5]}$, compensate for the loss caused by the failure of enterprise innovation activities, and improve enterprise innovation performance ${ }^{[6,7]}$. Some scholars believe that the target selection mechanism of government subsidies is not perfect, and it usually tends to vigorously subsidize enterprises in specific industries, which will accelerate overcapacity and undermine the fairness of market competition ${ }^{[8]}$. At the same time, the rent-seeking

\footnotetext{
* Corresponding author: 15021170153@163.com
} 
behavior of enterprises caused by information asymmetry [9] will weaken the subsidy effect ${ }^{[10]}$. Therefore, government subsidies will inhibit the improvement of enterprise innovation performance ${ }^{[11,12]}$. In addition, some scholars believe that there is an inverted U-shaped relationship between government subsidies and innovation performance. Before the critical point, government subsidies have an incentive effect, but beyond the critical point, they will have an inhibitory effect ${ }^{[13,14]}$.

Due to the differences in research perspectives, research contents and variable selection, the research conclusions are inconsistent. (1) From the perspective of research, most previous studies studied the impact of government subsidies on firm innovation from the perspective of innovation input, but there is a lack of research on the impact of government subsidies on innovation output. To improve the innovation level of enterprises, we should not only increase the innovation input, but also pay attention to the innovation output level and improve the utilization of resources. Therefore, it is of certain significance to study the influence of government subsidies on enterprise innovation from the perspective of innovation output. (2) In terms of research content, most of the existing literature studies the direct impact of government subsidies on enterprise innovation, but ignores the impact of the internal and external environment of enterprises on the subsidy effect. China is an emerging market country, and the internal governance structure of enterprises ${ }^{[15]}$, the degree of competition in various industries and the degree of corruption in different places are quite different, which will lead to a more complex mechanism of government subsidies' influence on enterprise innovation. Therefore, the analysis of the influence of ownership concentration, market competition and regional corruption on government subsidies and firm innovation performance is helpful to improve the effectiveness of assessing the effect of government subsidies. (3) In terms of innovation performance measurement, most existing literatures use the number of patent applications or sales revenue of new products to measure innovation performance. A single variable can only reflect a certain aspect of innovation activities, which is insufficient to comprehensively investigate the overall effect of innovation activities on enterprises, which may also reduce the authenticity of research conclusions.

In view of this, based on the technology innovation theory and the signal theory, this paper empirically tests the impact of government subsidies on the innovation performance of micro firms, and the moderating effect of regional corruption, market competition and ownership concentration on the relationship by taking A-share high-tech listed companies on Shanghai and Shenzhen stock exchanges from 2015 to 2019 as the research samples. The contribution of this paper is as follows: (1) this paper discusses the theoretical mechanism of government subsidies on enterprise innovation performance from the perspectives of macro region, medium industry and micro firm, which makes up for the deficiency of analyzing the effect of government subsidies on enterprise innovation performance from a single perspective in most existing studies; (2) the factor analysis method is used to construct the comprehensive evaluation index of innovation performance from three dimensions, which can more comprehensively reflect the overall effect of innovation activities on enterprises and make the research conclusions more accurate.

\section{Theoretical basis and research hypothesis}

\subsection{The impact of government subsidies on enterprises' technological innovation performance}

Technology innovation theory, has a "spillover effect", induce "price spillovers" and "knowledge spillovers", and a series of "free riding" behaviors by other enterprises, causes originally to innovation activities of enterprises can obtain proceeds at a relatively low cost technology imitation, innovation enterprise's profit is lower than the social benefits, reduce the managerial innovation enthusiasm, it is not conducive to innovation [16]. Government subsidies can make up for the technology spillover effect of enterprises, meet the expectations of managers, solve the problem of market failure, and promote technological innovation of enterprises [17]. Therefore, the central and local governments need to formulate and implement policies to support enterprise innovation, so as to make up for the damage caused by the spillover effect of innovation technology on enterprise managers' innovation enthusiasm. The practical experience of many countries shows that government subsidies can promote the performance of technological innovation. On the one hand, the resource nature of government subsidies can directly increase enterprises' income ${ }^{[4,5]}$, provide financial support for innovation activities, and improve enterprises' enthusiasm for innovation ${ }^{[18]}$. On the other hand, government subsidies can ease the financing constraints of enterprises. Because government subsidies have the function of transmitting high-quality signals, they send good signals to external investors and financial institutions that the innovation project is of high quality, has development potential and the enterprise has strong technical ability, attract external investors to inject capital and broaden the external financing sources of enterprises [7], thus alleviating the financing difficulties of enterprises. Government subsidies can also promote industry-university-research cooperation and reduce the risk of failure in innovation activities, thereby reducing the degree of risk aversion and improving the level of risk-taking of enterprises [6,7]. Based on the above analysis, the paper proposes the following hypotheses:

H1: Government subsidies have a significant promoting effect on enterprises' technological innovation performance. 


\subsection{Moderating effect of regional corruption}

Corruption usually refers to the abuse of public power or rights for private gain. Political economy holds that corruption will destroy institutional trust, which is necessary for enterprise innovation activities ${ }^{[19]}$. The listing of new products and the entry into new markets of enterprises must be subject to the approval and permission of relevant government departments. The lower the level of corruption in a region, the less the local government intervenes in the economic behavior of enterprises, the fairer the market competition, and the more fair the government subsidies to enterprises. In order to obtain more resources, enterprises will turn to increase innovation input and improve their own innovation level, so as to stimulate the enthusiasm of enterprises to carry out innovation activities ${ }^{[20]}$. In regions with a high level of corruption, corporate bribery will speed up the cumbersome approval process of the government, but will improve the R\&D efficiency of those enterprises eager to launch new products, and official corruption will promote enterprise innovation to a certain extent ${ }^{[21]}$.

However, some scholars argue that corruption can inhibit technological innovation. Due to the local corruption degree is higher, enterprise in order to speed up the tedious government approval process, easier to bribe local officials ${ }^{[22]}$, the lusts for corruption of government officials may accept bribes, undermine the government supervision and examination and approval system, refused to some potential quality innovation project examination and approval by some poor project [23]. At the same time, the bribery of enterprises will strengthen their political association with the government, thus obtaining more political asylum and government subsidies [24]. Political asylum will loosen the government's supervision over these enterprises, leading to the misuse of government subsidies by enterprises, thus reducing the effect of subsidies. Therefore, a high level of regional corruption will undermine the fairness of the government's support for innovation projects, not only impair the innovation enthusiasm of enterprises with high-quality innovation projects, but also reduce the effect of government subsidies. Based on the above analysis, the paper proposes the following hypotheses:

$\mathrm{H} 2$ : regional corruption degree has an inverted U-shaped moderating effect on the relationship between government subsidies and enterprise innovation performance.

\subsection{Moderation effect of market competition}

China's market environment is highly competitive and highly uncertain, and market factors may affect the effect of government subsidies. When market competition is encouraged, enterprises will invest more energy and resources to maintain survival, and pay less attention to technological innovation ${ }^{[25]}$. In this case, enterprises often use government subsidies to directly increase profits, relieve profit margin pressure, lack of enthusiasm and energy for technological innovation ${ }^{[26]}$, and the possibility of government subsidies to improve technological innovation performance will be reduced. However, when competition intensifies, technological innovation should become the focus of enterprises, so as to obtain long-term development advantages. In other words, the promotion of government subsidies to technological innovation will be weakened in the stimulating market competition environment. Based on this, this paper puts forward the following hypotheses:

H3: Market competition degree has a negative moderating effect on the relationship between government subsidies and enterprises' technological innovation performance.

\subsection{Moderating effect of corporate ownership concentration}

Ownership concentration refers to the proportion of shareholders in the total shares, which reflects the distribution of interests and power between the owners and managers of an enterprise, and is an important indicator for observing the corporate governance structure [27]. Under the condition of ownership concentration is high, large shareholders are more likely to put the interests of the individual and corporate interests closely, seek private interests at the expense of the small shareholders interests ${ }^{[28]}$, or normal operation is given priority to with personal interests too much intervention management decision-making and behavior, affect the enterprise innovation resources allocation and staff to give full play to the innovation, thus influence enterprise technology innovation performance.

However, there is no unified conclusion on the influence of ownership concentration on technological innovation performance. Another relative school of theory holds that ownership concentration can improve the performance of technological innovation. The higher ownership concentration can give full play to the supervision rights of major shareholders, reduce the agency conflict between shareholders and managers and the free-riding behavior among shareholders members caused by equity decentralization ${ }^{[29]}$, and thus improve the utilization rate of innovation resources of enterprises. Moreover, in the case of high ownership concentration, managers' innovation decisions will be valued, because managers' power is weakened and they do not need to bear the failure risk and loss of independent innovation, and the success of innovation will bring extra remuneration and social reputation to managers, which will stimulate managers' enthusiasm for innovation ${ }^{[30]}$. Studies show that for enterprises with high ownership concentration, controlling shareholders or actual controllers will pay more attention to technological innovation that can bring new markets and strong competitiveness to enterprises for long-term development, thus increasing long-term R\&D investment of enterprises ${ }^{[31]}$.Based on this, this paper proposes the following hypotheses:

H4: Ownership concentration has a U-shaped moderating effect on the relationship between government subsidies and firms' technological innovation 
performance.

To sum up, this paper constructs the conceptual model as shown in Figure 1.

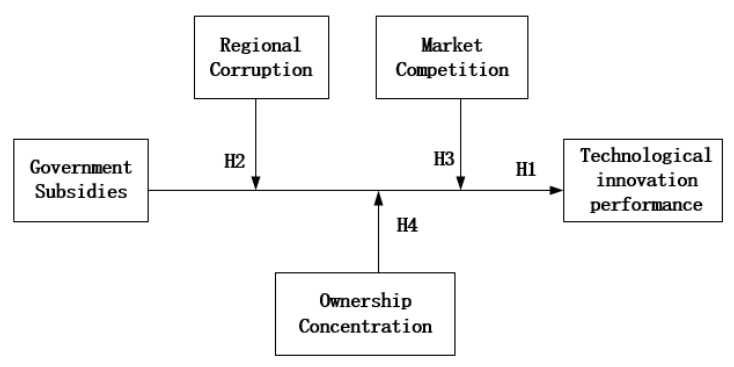

Figure 1 Conceptual model

\section{Selection of Samples, Variables and Indicators}

\subsection{Sample Selection and Data Sources}

Since high-tech enterprises have intensive research and development activities, high technology content, high added value of products and more attention to innovation activities, this paper selects high-tech enterprises listed in A-share market from 2015 to 2019 as the research object, excluding ST and $\mathrm{ST}^{*}$ as well as listed enterprises with incomplete data, and finally gets the data of 393 listed enterprises. The data for this article are from CSMAR database, WIND database, annual reports of listed companies and China Population and Employment Statistical Yearbook.

\subsection{Selection of variables and indicators}

(1) Explained variable: technological innovation performance (EIP). In order to more comprehensively reflect the overall effect of technological innovation activities on enterprises, on the basis of references ${ }^{[32-34]}$, a measurement index system of technological innovation performance is constructed from three dimensions of innovation input, innovation direct benefit and innovation indirect benefit, and the index is given weight through factor analysis method.

(2) Explanatory variable: government subsidy (Sub). Government subsidies include direct subsidies and indirect subsidies. Based on the availability of data and the purpose of this study, this paper does not distinguish between direct subsidies and indirect subsidies, and chooses the "government subsidies" data under the item of "non-operating income and expenditure" in the notes to the financial statements of listed companies to measure.

(3) Moderating variable: regional corruption (Politic). Refer to Sun ${ }^{[35]}$, which measures "the number of duty crimes published by the procurator rate per 10,000 employees of state-owned units". market competition (HHI). Referring to Jiang ${ }^{[36]}$, the Herfindal-Hirschmann index (HHI) was adopted to measure the degree of market competition. Ownership concentration (Con). By referring to Peng ${ }^{[37]}$, the shareholding ratio of the largest shareholder is used to measure.

(4) Control variables: referring to relevant studies at home and abroad ${ }^{[32,38]}$, property right nature, enterprise size, enterprise age, profitability and debt paying ability that have important influence on technological innovation performance and government subsidies are taken as control variables. The descriptive statistical analysis of the samples is shown in Table 1.

Table1 Descriptive statistical analysis of the samples

\begin{tabular}{|c|c|c|c|c|c|c|c|c|c|c|}
\hline Variable & EIP & Sub & Politic & HHI & Con & State & Size & Age & Roe & Lev \\
\hline EIP & 1 & & & & & & & & & \\
\hline Sub & $0.214 * * *$ & 1 & & & & & & & & \\
\hline Politic & $0.094 * * *$ & $0.211 * * *$ & 1 & & & & & & & \\
\hline HHI & $-0.050 * *$ & -0.033 & $-0.064 * * *$ & 1 & & & & & & \\
\hline Con & $0.017 * *$ & $0.091 * * *$ & -0.016 & $-0.043^{*}$ & 1 & & & & & \\
\hline State & $0.221 * * *$ & $0.175 * * *$ & $0.081 * * *$ & $-0.183 * * *$ & $0.048 * *$ & 1 & & & & \\
\hline Size & $0.420 * * *$ & $0.283 * * *$ & $0.259 * * *$ & $-0.150 * * *$ & 0.002 & $0.381 * * *$ & 1 & & & \\
\hline Age & $0.147 * * *$ & $-0.073 * * *$ & -0.022 & 0.020 & $-0.081 * * *$ & $0.287 * * *$ & $0.192 * * *$ & 1 & & \\
\hline Roe & $0.114 * * *$ & $0.121 * * *$ & $0.081 * * *$ & $0.064 * * *$ & $0.158 * * *$ & -0.017 & $0.092 * * *$ & $-0.043^{*}$ & 1.000 & \\
\hline Lev & $0.169 * * *$ & $0.100 * * *$ & $0.111 * * *$ & $-0.247 * * *$ & $-0.093 * * *$ & $0.241 * * *$ & $0.505 * * *$ & $0.150 * * *$ & $-0.218 * * *$ & 1.000 \\
\hline
\end{tabular}

\section{Empirical analysis}

\subsection{Research model}

This paper constructs the following regression model to test the influence of government subsidies on enterprises' technological innovation performance, as well as the moderating effects of regional corruption degree at the macro level, market competition degree at the medium level and ownership concentration degree at the micro level.

(1) $\mathrm{EIP}_{\text {it }}=\beta_{0}+\beta_{1} \mathrm{Sub}_{\text {it }}+\sum \beta_{\mathrm{k}} \times$ controls $_{\text {it }}+\varepsilon_{\text {it }}$

(2) EIP $_{\text {it }}=\beta_{0}+\beta_{1}$ Sub $_{\text {it }}+\beta_{2}$ Politic $_{\text {it }}+\beta_{3}$ Sub $_{\text {it }}$ $\times$ Politic $_{i t}+\beta_{4}$ Sub $_{\text {it }} \times$ Politic $_{\text {it }}^{2}+\sum \beta_{\mathrm{k}} \times$ controls $_{\text {it }}+\varepsilon_{\text {it }}$

(3) $\mathrm{EIP}_{\text {it }}=\beta_{0}+\beta_{1} \mathrm{Sub}_{\text {it }}+\beta_{2} \mathrm{HHI}_{\text {it }}+\beta_{3} \mathrm{Sub}_{\text {it }} \times \mathrm{HHI}_{\text {it }}$ 
$+\sum \beta_{\mathrm{k}} \times$ controls $_{\text {it }}+\varepsilon_{\text {it }}$

(4) $\mathrm{EIP}_{\text {it }}=\beta_{0}+\beta_{1} \mathrm{Sub}_{\text {it }}+\beta_{2} \mathrm{Con}_{\text {it }}+\beta_{3} \mathrm{Sub}_{\text {it }} \times \mathrm{Con}$ ${ }_{\text {it }}+\beta_{4} \operatorname{Sub}_{\text {it }} \times \operatorname{Con}^{2}{ }_{\text {it }}+\sum \beta_{\mathrm{k}} \times$ controls ${ }_{\text {it }}+\varepsilon \varepsilon_{\text {it }}$

Where, $i$ and $t$ represent enterprise and year respectively, and controls represent control variables. The interaction terms of government subsidy and regional corruption, government subsidy and market competition, and government subsidy and ownership concentration are added to the model to test the moderating effects of regional corruption, market competition and ownership concentration. Hausman test results $(\mathrm{P}=0.0000)$ indicated that the fixed-effect model was suitable for use.

\subsection{Regression analysis}

Regression analysis is mainly divided into the following four parts: (1) taking innovation performance as the dependent variable and government subsidies as the independent variable, a regression equation is constructed to verify the main effect of $\mathrm{H}_{1}$; (2) using the interaction term of regional corruption, government subsidies and regional corruption as independent variables, a regression equation was constructed to verify the moderating effect of $\mathrm{H}_{2}$. (3) taking the interaction term of market competition, government subsidies and market competition as independent variables, a regression equation was constructed to verify the moderating effect of $\mathrm{H}_{3}$. (4) using the interaction term of ownership concentration, government subsidies and ownership concentration as independent variables, a regression equation was constructed to verify the moderating effect of $\mathrm{H}_{4}$. In the above models, property right nature, firm size, firm age, profitability and debt paying ability are introduced as control variables.

Table 2 Fixed effect regression results

\begin{tabular}{|c|c|c|c|c|c|c|}
\hline variable & Model 1 & Model 2 & Model 3 & Model 4 & Model 5 & Model 6 \\
\hline State & $17.533 * * *$ & $17.459 * * *$ & $17.256^{* * *}$ & $20.371 * * *$ & $15.436 * *$ & $16.049 * *$ \\
\hline Size & $42.862 * * *$ & $42.161 * * *$ & $41.501 * * *$ & $43.227 * * *$ & $42.471 * * *$ & $41.668 * * *$ \\
\hline Age & $1.350 * *$ & $1.299 * *$ & $1.351 * *$ & $1.2321 * *$ & $1.477 * * *$ & $1.486 * * *$ \\
\hline Roe & $60.252 * * *$ & $61.351 * * *$ & $62.818 * * *$ & $61.686 * * *$ & $49.099 * *$ & $49.836 * *$ \\
\hline Lev & $-35.000 * *$ & $-33.343 *$ & $-31.436^{*}$ & -28.028 & -28.053 & $-28.376^{*}$ \\
\hline Sub & $4.573 * * *$ & $4.943 * * *$ & $6.090 * * *$ & $4.667 * * *$ & 0.040 & $5.097 *$ \\
\hline Politic & & -0.024 & -0.020 & & & \\
\hline Sub $\times$ Politic & & $0.023 * * *$ & & & & \\
\hline Sub $\times$ Politic $^{2}$ & & & $-0.001 *$ & & & \\
\hline HHI & & & & $120.727 * * *$ & & \\
\hline $\mathrm{Sub} \times \mathrm{HHI}$ & & & & $-25.726 * *$ & & \\
\hline Con & & & & & $71.702 * * *$ & $60.061 * * *$ \\
\hline $\mathrm{Sub} \times \mathrm{Con}$ & & & & & $19.178 * *$ & \\
\hline $\mathrm{Sub} \times \mathrm{Con}^{2}$ & & & & & & $148.239 * * *$ \\
\hline _cons & $-922.679 * * *$ & $-908.475 * * *$ & $-896.007 * * *$ & $-932.320 * * *$ & $-934.578 * * *$ & $-914.798 * * *$ \\
\hline $\mathrm{R}^{2}$ & 0.200 & 0.203 & 0.205 & 0.195 & 0.208 & 0.214 \\
\hline $\mathrm{N}$ & 1965 & 1965 & 1965 & 1965 & 1965 & 1965 \\
\hline
\end{tabular}

Note: ${ }^{*}, *$ and $* * *$ indicate significant at $10 \%, 5 \%$ and $1 \%$ levels, respectively.

(1) main effect test: according to the regression results, government subsidies (Sub) and enterprise innovation performance (EIP) are significantly positively correlated $(\beta=4.573, \mathrm{P}<0.01)$, indicating that government subsidies have a significant promoting effect on enterprise innovation performance. Hypothesis $\mathrm{H}_{1}$ is verified; (2) moderation effect test: stratified regression was used to test the moderating effect. Model 2 and Model 3 are the first and second cross terms of moderating variable regional corruption (Politic), independent variable government subsidy (Sub) and moderating variable regional corruption (Politic), which are gradually added on the basis of Model 1.The test results are shown in Table 2. The regression coefficient of Politic is not significant. The influence coefficient of primary cross-term is positive $(\beta=0.023)$, but the coefficient of secondary cross-term is significantly negative $(\beta=-0.001, P<0.1)$ at the $1 \%$ level. It shows that regional corruption has an inverted "U-shaped" moderating effect on the relationship between government subsidies and firm innovation performance, and hypothesis $\mathrm{H}_{2}$ is verified. The moderating effect of inverted $U$ shape indicates that excessively serious regional corruption will reduce the promotion effect of government subsidies on enterprise innovation, and only moderate regional corruption level will play the role of strengthening the effect of government subsidies.

Model 4 is a cross term of HHI, government subsidy (Sub) and HHI based on Model 1. The test results show that the regression coefficient of regulatory market competition (HHI) is significant $(\beta=120.727, \mathrm{P}<0.05)$, and the regression coefficient of government subsidies increases from 4.573 to 4.667 , indicating that market competition has a certain moderating effect on the relationship between government subsidies and innovation performance. In addition, the first cross term coefficient of market competition and government subsidies is significantly negative at the level of $5 \%$, indicating that market competition negatively moderates the relationship between government subsidies and innovation performance.

Model 5 and Model 6 are the first and second cross terms of moderating variable ownership concentration (Con), independent variable government subsidy and moderating variable ownership concentration on the basis of Model 1. The regression results showed that the 
regression coefficient of government subsidy (Sub) was significantly positive $(\beta=5.097, \mathrm{P}<0.1)$, the regression coefficient of ownership concentration (Con) was significantly positive $(\beta=60.061, \quad \mathrm{P}<0.01)$, and the interaction coefficient of ownership concentration square and government subsidy was significantly positive at the $1 \%$ level $(\beta=148.239, \mathrm{P}<0.01)$, which indicates that ownership concentration (Con) plays a U-shaped moderating role in the relationship between government subsidies and enterprise innovation performance. This is because the decentralization of the ownership structure will hinder the major shareholders from exerting their supervision rights over the enterprise operators, and shareholders are also prone to free riding behavior, thus weakening the effect of government subsidies. When the degree of ownership concentration exceeds a certain threshold, the personal interests of major shareholders are closely related to the development of the enterprise. At this time, major shareholders will strengthen the internal supervision of the enterprise to improve the effect of government subsidies for the long-term development of the enterprise.

\section{Conclusions and recommendations}

\subsection{Conclusion}

China's sustainable development cannot be separated from the continuous technological progress, which depends on the innovation activities of enterprises. Based on the panel data of listed high-tech enterprises with intensive R\&D activities and more focus on innovation activities from 2015 to 2019, this paper studies whether government subsidies can improve the innovation performance of enterprises and the influence of internal and external environment of enterprises on the effect of government subsidies. The results show that : (1) government subsidies can not only directly increase the innovation funds of enterprises, but also send a high-quality signal that the innovation projects are of high quality and have development potential, which can help enterprises to expand external financing and obtain more technical support, thus promoting enterprise innovation; (2) the regional corruption has an inverted U-shaped moderating effect on the government subsidy effect, that is, moderate corruption is conducive to enhancing the subsidy effect, but too high level of corruption will reduce the subsidy effect and inhibit enterprise innovation. This is because when the system is defective, corruption is likely to become a cost for innovative enterprises to seek government protection. When the cost exceeds the benefits of enterprises' innovation ${ }^{[25]}$, corruption will reduce the subsidy effect. (3) market competition moderates the subsidy effect negatively, that is, the more intense the market competition is, the weaker the promoting effect of government subsidies on the innovation performance of enterprises. (4) ownership concentration has a positive U-shaped moderating effect on the relationship between subsidies and innovation performance. That is, when the ownership concentration is low, the ownership concentration plays a negative regulating role; when ownership concentration is high, ownership concentration positively moderates the impact of government subsidies on firm innovation performance.

\subsection{Suggestions}

According to the research conclusions, the following suggestions are put forward : (1) for the government, (1) the government should continue to increase the investment in R\&D activities of enterprises, give full play to the signal transmission function of government subsidies, attract more external innovation resources, and stimulate the technological innovation of enterprises; (2) the effective play of the subsidy effect needs the effective cooperation of the internal and external environment of the enterprise. Serious regional corruption will weaken the effect of government subsidies. Therefore, the Chinese government and relevant institutions should severely punish high-level corruption activities, further improve the market mechanism and improve the efficiency of resource allocation. According to the different internal and external environment of the enterprise, make different subsidy policies; (3)Governments at all levels should strengthen the establishment and improvement of the enterprise internal control system; (2) for enterprises: (1)enterprise managers should cultivate the consciousness of long-term development, actively respond to national policies, give full play to the signal role of subsidies, and actively "show themselves" to the outside world, broaden the source of innovation funds and introduce technical personnel, improve the ability of independent innovation; (2) the enterprise senior managers should be fully aware of the importance of improving the enterprise internal control system for enterprise research and development activities and a series of other business activities, consciously cooperate with the government and the relevant departments to supervise and guide.

\section{References:}

1. Wang, J. (2010) An Empirical Study on the Influence of R\&D Subsidy on R\&D Input and Innovation Output of Enterprises. J. Scientific Research, 28: 1368-1374.

2. Li, A.L. (2015) Research on the effect of government R\&D funding on firm innovation output. J. Statistics and Decision, 16: 185-188.

3. Tether, B.S. (2002) Who co-operates for innovation and why: an empirical analysis. J. Research Policy, 31: 947-967.

4. Bai, J.H. (2011) Is Government R\&D Subsidies Effective in China? Empirical evidence from large and medium-sized industrial enterprises. J. Economics Quarterly, 10: 1375-1400.

5. Guo, D., Guo, Y., et al. (2016) Government-subsidized R\&D and firm innovation: evidence from China. J. Research Policy, 45: 
1129-1144.

6. Wu, J., Huang, D.M. (2016) Research subsidies, industry-university-research cooperation and strategic emerging industry innovation. J. Science Research Management, 37: 20-27.

7. Yan, R.S., Chen, J., et al. (2020) The impact of government subsidies on firm innovation investment based on financing constraints and the intermediation effect of firm risk taking. J. Journal of Management, 17: 1188-1198.

8. Geng, Q., Jiang, F.T., et al. (2011) China's economic fluctuations: A case study of the RBC model of capacity utilization. J. China Industrial Economics, 28: 27-36.

9. Zhang, J., Chen, Z.Y., et al. (2015) Economic Research Journal, 50: 4-17+33.

10. Guo, Y. (2018) The role of government subsidies in innovation. J. China Industrial Economics, 35: 98-116.

11. Li, W.F., Du, J., et al. (2017) Innovation subsidies incentivize enterprises to invest in innovation: Evidence from Chinese listed companies. J. Financial Research, 10: 130-145.

12. Liu, Y.X., Zhang, Z. (2020) The impact of government funding on industry-university-research collaborative innovation performance: Data from Jiangsu Province. J. Science and Technology Management Research, 40: 42-47.

13. Hussinger, K. (2008) R\&D and Subsidies at the Firm Level: an Application of Parametric and Semiparametric Two-step Selection Models. J. Journal of Applied Econometrics, 23: 729-747.

14. Yao, W.B., Zhang, Y.F. (2020) Government subsidy, external financing choice and firm innovation performance: An empirical study based on panel data of China's listed manufacturing firms. J. Technology Economics, 39: 63-69.

15. Mao, Q.L., Xu, J.Y. (2015) The impact of government subsidies on new product innovation: A perspective from the "moderate range" of subsidy intensity. J. China Industrial Economics, 6: 94-107.

16. Xing, H., Wang, F., et al. (2019) A review of the relationship between government policy support and enterprise innovation. J. Journal of Finance and Accounting, 17: 130-135.

17. Yang, Z.Q., Zhang, F., et al. (2019) How government subsidies affect firm innovation in competitive fields. J. Finance and Trade Economics, 40: 132-145.

18. Li, X.J., Yang, H. (2019) Fiscal and Tax Incentive Policies, External Environment and Firm R\&D Investment: An Empirical Study of A-share Listed Companies in China's Strategic Emerging Industries. J. Contemporary Finance and Economics, 3: 25-36.

19. Rodriguez, P., Eden, L., et al. (2005) Government corruption and the entry strategies of multinationals. J. Academy of Management Rev.30: 383-396.

20. Ai, S.W.M.E.J., Zheng, H., et al. (2020) Research on the influence of R\&D investment on regional innovation capacity based on institutional environment threshold model. J. Journal of Xinjiang University (Philosophy, Humanities and Social Sciences), 48: 13-25.

21. Kaufmann, D., Wei, S. (1999) "Does 'Grease Money' Speed Up the Wheels of Commerce?" NBE R Working Paper, No. 7093.

22. Olken, B.A., Pande, R. (2012) "Corruption in Developing Countries". J. Annual Review of Economics, 4: 479-509.

23. See, C.Y.C. (1998) Learning by Doing, the Technology Gap, and Growth. J. International Economic Review, 39:.697-721.

24. Xu, C., Sun, Y.X. (2018) The Impact of Corruption on Firm Innovation and Rent-seeking under Competitive Pressure. J. Foreign Economics and Management, 40: 129-143.

25. Chen, Y.F., Jin, B.X., et al. (2020) The impact of corporate social responsibility on the performance of technological innovation. J. Science Research Management, 41: 87-98.

26. Kang, Z.Y., Tang, X.L., et al. (2018) "Can you have your cake and eat it too"?. J. Journal of Economic Economics, 4: 101-117.

27. He, X.B., Zhu, D.Y., et al. (2020) The two dimensions of shared leadership and firm innovation performance. J. Studies in Science of Science, 38: 747-758.

28. Chen, V.Z., Li, J., et al. (2011) Are OECD-prescribed "good corporate governance practices" really good in an emerging economy?. J. Asia Pacific Journal of Management, 28: 115.

29. Ma, S.H., Naughton, T., et al. (2010) Ownership and ownership concentration: which is important in determining the performance of China's listed firm? J. Accounting and Finance, 50: 871.

30. Yang, J.J., Wang, T., et al. (2015) Ownership concentration and independent innovation behavior: Based on the perspective of behavioral motivation. J. Management Science, 28: 1-11.

31. Yang, H.J., Yang, J.J. (2015) Ownership concentration, executive motivation and technological innovation choice. J. Science Research Management, 36: 48-55.

32. Dai, X.Y., Cheng, L.W. (2013) Research on the threshold effect of R\&D investment intensity on enterprise performance. J. Scientific Research, 31: 1708-1716+1735.

33. Burke, P.F. (2007) Measuring patent assessment quality-analyzing the degree and kind of (in) consistency in patent offices' decision making. J. Research Policy, 36: 1404-1430.

34. Wu, W.H., Yao, L.H. (2014) Research on the influence of core stock ownership incentive on innovation performance of listed companies in strategic emerging industries. J. Science and 
Technology Progress and Countermeasures, 31: 75-79.

35. Sun, M., Geng, S. (2019) The Corruption Trap Across Market Transition: The Inverted U-Shaped Relationship between Regional Marketization and Corruption [J].Social Science, 12: 12-24.

36. Jiang, F.X., Huang, L., et al. (2009) Product Market Competition, Corporate Governance and Agency Costs. J. World Economy, 32: 46-59.

37. Peng, Z.W., Wen, Y.H., et al. (2015) The impact of government subsidies on the performance of new energy enterprises: The moderating role of corporate internal governance. J. Journal of Central University of Finance and Economics, 07: 80-85.

38. Liu, G.Q. (2016) The incentive effect of tax incentives and fiscal subsidies: An empirical study from the perspective of information asymmetry theory. J. Management World, 10: 62-71. 